\title{
Role of SMEs in the Economic and Social Development: Case of Terroir Products in Souss Massa Draa Region (Morocco)
}

\author{
Bellihi Hassan*, Bazi Mohamed \\ National School of Business and Management, Ibnou Zohr University, Morocco
}

Copyright (C) 2015 by authors, all rights reserved. Authors agree that this article remains permanently open access under the terms of the Creative Commons Attribution License 4.0 International License

\begin{abstract}
The study of entrepreneurship as well as Small and Medium-sized Enterprises (SMEs) interests more and more the practitioners, politicians and academics around the world seen their weight in the global economy. Small and Medium-sized Enterprises have no universal definition but are rather defined by their size based on their number of employees, Balance sheet total and Turnover whose boundaries differ from one country to another. Driven by entrepreneurship, SMEs represent a real lever for economic and social growth especially in emerging economies level. Now, it is generally accepted that Small and Medium-sized Enterprises are endowed with a potential of innovation, job creation and income growth. Thus, in a global context, SMEs in developing countries try to survive and to expand their activities on other markets which is not an easy task. So, the difficulty of the context in which they operate makes it a model worth studying. Our paper aims to draw up the profile of SME entrepreneurs in the field of terroir products in Souss Massa Draa (Morocco) region in order to understand their main motivations and aspirations. So we shall clarify the main obstacles facing these entrepreneurs on one hand and the important role they play in Moroccan economy on the other hand. Our study suggests adopting a strategy based on network weaving to better promote terroir products and contribute to the sustainable development of the region. This strategy must be accompanied with the independence from financing to allow these SMEs to grow up and reach an international dimension. The contribution of this paper is therefore to suggest to researchers in entrepreneurship to focus on theories such as resource based view or stakeholder theory to better understand the issues related to small and medium terroir businesses.
\end{abstract}

Keywords Developing Countries, Economic, Entrepreneurship, SME, Social

\section{Introduction}

The study of entrepreneurship as well as Small and Medium-sized Enterprises (SMEs) interests more and more the practitioners, politicians and academics around the world seen their weight in the global economy. Entrepreneurship and SMEs are closely linked and contribute effectively to the development worldwide. The aim of this paper is to draw up the profile of SME entrepreneurs in the field of terroir products to highlight their contribution in their turbulent rural contexts and to clarify their main obstacles beside their important role in the economic and social local development. Our research issue can be formulated as follows: What are the most important success factors for terroir entrepreneurs? And what factors are most crucial for them?

We'll start by drawing a literature review of SMEs to highlight the strong link between entrepreneurship and SMEs to clarify the relevance of our research that crosses between the two fields. Also, we will demonstrate the contribution of SMEs to national economies before looking at the specific case of terroir ones in emerging economies where the debate on the social role of SMEs is most present. Indeed, we will show that the contribution of SMEs is crucial for economic and social development in a global scale. In this way, the results of our research can be generalized in several contexts.

To respond to our research issue, we will conduct a qualitative study in order to understand the terroir entrepreneurs' perception of entrepreneurial success in their turbulent context. We will subsequently conduct a quantitative study to measure the priority given by the entrepreneurs to the main variables selected for their success. 


\section{Small and Medium-sized Enterprises: A Literature Review}

\subsection{From Entrepreneurship to SMEs}

Entrepreneurship is a field of study that examines the entrepreneurs as well as the economic and social effects of their behaviors Filion [1] (p. 156). It is a multidimensional field that continues to interest researchers, practitioners and politicians worldwide. Today, there is no doubt about the contribution of the entrepreneurial act to the economic development [2,3]. Thus, nations incite to the entrepreneurship and integrate it into the majority of their debates aware of his role. Indeed, the local and regional development passes necessarily by the stimulation of entrepreneurship in the sense that it allows to generate jobs and increase incomes OECD[4]. Naturally, stimulate entrepreneurship is necessary for development but remains insufficient because national conditions (Economic Growth, population growth, culture, and national entrepreneurship policy) influence the opportunities which are vital to foster the entrepreneurial act [5]. Entrepreneurship corresponds to the starting up of a business and to the creating value for the entrepreneurs as well as for the community [6]. Entrepreneurship is therefore intimately linked to the Small and Medium-sized Enterprise (SME) seen that the act of creation generally gives birth to small structures $[7,8]$. This overlap between the SME and Entrepreneurship clears up when we dig into history. In 1953, the United States Congress voted the Small Business Act to promote SMEs in the economy. In the late 1970s, Prime Minister and French economist Raymond Barre has invited every unemployed person to take his fate in hand by creating his own work rather than relying on an employer. The purpose of this strategy was to transform the plague of unemployment into an asset contributing to the economic and social development through entrepreneurship. Thus, the logic of the SME as a development key began little by little to substitute itself for that where the progress of a country was only attributable among its large companies. Therefore, the years 1970-1985 have marked the transition from "big is efficient" to "small is beautiful". These years were marked by a growing interest among researchers for SMEs as denotes the small business innovation Development Act (United States -1982) or the Trois-Rivières conference of 1984, which will result, a few years later in the creation of one of the most well-known research groups in SMEs the AIREPME (International Association for Research in Entrepreneurship and SMEs). Since the 1970s, SMEs are perceived as an engine of economic growth as well as a surefire way to innovation and performance. Today, the term "entrepreneur" in French refers directly to any manager of a SME [8], letting think that the study of SMEs passes inevitably by the entrepreneur and his environment. Accordingly, if entrepreneurship is a multidimensional concept that obeys to the rules of the environment in which it operates, we shall also see that SMEs are defined differently worldwide.

\subsection{Definition of SME}

Although the SMEs interests researchers and practitioners worldwide, they have never agreed about a generally accepted definition. Indeed, SMEs are defined differently by each nation according to its economic development phase and social environment [9]. Thus, the idea of unanimity around a single definition is utopian. As we have seen, it is in the 70s that the SMEs started to be recognized as an engine of economic growth and development. One of the earliest references to SMEs concerns the 1971's report of the "Bolton Commitee" concerning the British firms. According to the national archives of United Kingdom, Bolton Committee defines a "small firm as an independent business, managed by its owner or part-owners and having a small market share"1. This definition which presents purely qualitative characteristics of the SMEs will inspire several contemporary researchers. These researchers will focus on qualitative definitions of SMEs based on intrinsic variables such as the mode of decision-making [10], the presence of the owner in the management of the company [11], the predominance of family management style etc. In general, qualitative definitions of SMEs refer directly, for their great majority, to the entrepreneur's position in the creation and management process. However, even if the debate on the integration of qualitative data in the definition of SMEs is present in the literature, national economies prefer to refer to quantitative data which are more pragmatic. These definitional criteria of SMEs generally concern data such as the annual balance sheet total (refers to the value of the company's main assets), The annual turnover (determined by calculating the annual income of the enterprise without including value added tax (VAT) or any other indirect tax) or The staff headcount (includes the owner-managers, employed, persons working for the enterprise, Partners Benefiting from financial advantages from the enterprise.) $[9,12]$. The following table summarizes some definitions of SMEs worldwide. For developing countries, we wanted to collect some data of countries close to the Moroccan economic and social context.

The lack of coherence in the definition of SMEs worldwide makes difficult their comparison. Thus, we confine ourselves in this section to highlight the overall importance of SMEs in some countries to show the weight of these enterprises in the global economy prior to focus on their impact in the developing countries and specifically in Morocco.

\footnotetext{
http://webarchive.nationalarchives.gov.uk/+/http://www.dti.gov.uk/sme4/de fine.htm (Retrieved 20/06/2014)
} 
Table 1. Definitions of SMEs worldwide.

\begin{tabular}{|c|c|c|c|c|}
\hline Country & $\begin{array}{c}\text { Doing Business } 2014 \\
\text { Ranking }\end{array}$ & Number of employees & Annual turnover & $\begin{array}{c}\text { Balance sheet } \\
\text { total }\end{array}$ \\
\hline \multicolumn{5}{|c|}{ Developed countries } \\
\hline Canada $^{2}$ & 19 & $<500$ & Not applicable & Not applicable \\
\hline European Union ${ }^{3}$ & Not applicable & $<250$ & $\leq € 50$ million & $\leq € 43$ million \\
\hline Singapore $^{4}$ & 1 & $<200$ & S\$100 million & Not applicable \\
\hline United Kingdom $^{5}$ & 10 & $<250$ & $\leq £ 11.2$ million & $\leq £ 5.6$ million \\
\hline United States $^{6}$ & 4 & $<500$ & $\leq \$ 7$ million & Not applicable \\
\hline \multicolumn{5}{|c|}{ North African Developing countries } \\
\hline Algeria $^{7}$ & 153 & $<250$ & Dinar 2 billion & Dinar 500 million \\
\hline Egypt & 128 & $<50$ & Not applicable & Not applicable \\
\hline Morocco $^{8}$ & 87 & $<200$ & $<$ MAD 75 million & $<$ MAD 50 million \\
\hline Tunisia $^{9}$ & 51 & $<300$ & Not applicable & Not applicable \\
\hline \multicolumn{5}{|c|}{ Institutions } \\
\hline African Development Bank & Not applicable & $<50$ & Not applicable & Not applicable \\
\hline World Bank & Not applicable & $<300$ & $\leq \$ 15$ million & $\leq \$ 15$ million \\
\hline
\end{tabular}

\subsection{Contribution of SMEs in National Economies}

Significance of small and medium sized enterprises (SMEs) to the economy and society in terms of their contribution to output and employment is now indisputable [13]. Besides its role of economic lung, The World Bank's Doing Business reports indicate that a healthy SME sector corresponds with a reduced level of informal or "black market" activities [14]. SMEs have an important role both economically and socially, but also on reducing the informal economy in countries what makes them vital for the local, regional and international development. Seen the absence of a unanimous definition of SMEs across the world, we will limit ourselves to highlight the role some SMEs play in their contexts without proceeding to any comparison.

2 From Environment Canada http://ec.gc.ca/p2/default.asp?lang=En\&n=D35E8873-1

3 Article 2 of the Annex of Recommendation 2003/361/European Commission ( under the number C(2003) 1422]. Official Journal of the European Union.

4 From Spring Singapore http://www.spring.gov.sg/aboutus/pi/pages/performance-indicators.aspx

5 (From : http://www.dti.gov.uk/sme4/smehome.htm ) if it satisfies at least two of the following criteria. See Section 248 of the Companies Act of 1985.

6 United States International Trade Commission. 2010. 2-3

7 SME orientation act $\mathrm{n}^{\circ} 01-18$ du 12.12.2001, SME's ministry Algeria.

8 (from: http://www.dti.gov.uk/sme4/smehome.htm ) if it satisfies at least two of the following criteria. See Section 248 of the Companies Act of 1985.

(Retrieved 11/06/2014)

9 Official statement of financial market (CMF), Bulletin du CMF 2588 (May $3^{\text {rd }} 2006$ ). 
In 2012, the 20 million European SMEs have played an important role in the economy of the Eurozone. These SMEs have registered 86.8 million jobs representing $65.5 \%$ of jobs in Europe in the same year [15]. Today, European SMEs represent $99 \%$ of all businesses and are the engine of economic growth, innovation, job creation and social integration [16]. The SMEs importance is also felt in the Asian economies [9]. Indeed, SMEs are deeply anchored in the Asian economy. In Japan, 99\% of businesses are SMEs generating $69 \%$ of total employment and $53 \%$ of value added. It's the same for Singapore, first country on the ease of doing business following the report of the World Bank [17]. Indeed, this ranking is the result of an economy compounded of $99 \%$ of SME employing $70 \%$ of the population (7 out of every 10 workers) and contributing to $50 \%$ to the national $\mathrm{GDP}^{10}$. In the United States, Small businesses are the backbone of the U.S. economy and the primary source of jobs for Americans (Office of the United States Trade Representative). The Small Business and Entrepreneurship Council ${ }^{11}$ reported in 20115.68 million employer firms of which $99.7 \%$ are SMEs. In 2011, these companies were responsible for $33 \%$ of total exports. According to U.S. Census Bureau data ${ }^{12}$, between 1993 and 2013, SMEs were responsible for $63 \%$ of job creation (that is to say 14.3 of the 22.9 million new jobs). Thus, according to the same source, after the 2009 recession, SME has played a mattering social role by generating $60 \%$ of the new jobs (from mid 2009 to mid 2013).

SMEs are as important in developed countries as in emerging countries [18]. Indeed, the role of SMEs in these countries may leave understand that social ambition (reducing unemployment) is more present than economic ambition (creating competitive business) [8] (p. 152). However, most of the SMEs operating in emerging countries suffer from the difficulty of facing the competitors in a globalized context. This competition in terms of costs quality and productivity affects their capacity of investment and financing thus weakening their potential for growth and development.

For North African economies, the turbulence of the social, political and economic environment poses a real challenge to their SMEs. As a result, economies of North Africa rely on the dynamic and adaptability of their SMEs in order to enhance their competitiveness and restructure their economies [19]. In Egypt, three-quarters of new employment generations are caused by SMEs which constitute more than $99 \%$ of all non-agricultural private enterprises [20]. This situation is reproduced in Libya where $96 \%$ of companies are SMEs contributing to $93 \%$ employment [19]. In Tunisia, 97\% of companies are SMEs (Agency for the Promotion of Industry, June 2002.). However, these SMEs are composed of individual companies without job creation capacity among which $66 \%$

10 Spring Singapore. Retrieved 30/06/2014.from

http://www.spring.gov.sg/aboutus/pi/pages/performance-indicators.aspx

11 http://www.sbecouncil.org/about-us/facts-and-data/ (Retrieved 06/07/2014)

$12 \mathrm{http}: / /$ www.census.gov/econ/susb/ suffer from financial problems ${ }^{13}$. These problems are also present in Algeria, where $95 \%$ of companies are SMEs among which $90 \%$ have a family character. In Morocco, country of the study, more than $95 \%$ of companies are SMEs. Their contribution in the economy is thus crucial. , they are the authors of $20 \%$ of the value added and account for $40 \%$ of production [21]. However, as in any developing country, these companies represent a fragile and fragmented tissue with low growth. Aware of the importance of SMEs in development scene, the Moroccan state established several reforms to promote them (supports for the creation, fiscal incentives, booking $20 \%$ of the budget allocated to public markets ...). These reforms have had a positive effect on the national economy propelling Morocco from the 97th position to $87 \mathrm{th}^{14}$ position between 2013 and 2014 according to the World Bank doing business report. Accordingly, in addition to having an impact on the Moroccan economy, these companies generate social value by employing more than $50 \%$ of the Moroccan workforce. Thus, the contribution of SME in national economies is well established. In the theater of development, the role played by SMEs and micro firms is very important not only because they are defined as the growth engine but also because they represent the largest percentage of firms in the Economic Activity. This role is particularly important in emerging economies where the debate on the social role of SMEs is most present. We shall so concern ourselves with the terroir sector in order to clarify this role.

\section{Context of the Study}

\subsection{The SME of Terroir}

As we have shown, SMEs play an important role in the development of the economies worldwide. A role becomes accentuated in developing countries where economic and social problems are more pressing. Indeed, these countries are characterized by the presence of rural areas which slow down the growth process initiated by the cities. Following the example of the Souss Massa Draa Morocco region, these rural zones abound of human and cultural heritage on one hand and authentic products (terroir products) on the other hand. According to UNESCO (2005), « A Terroir is a geographical limited area where a human community generates and accumulates along its history a set of cultural distinctive features, knowledges and practices based on a system of interactions between biophysical and human factors. The combination of techniques involved in production reveals originality, confers typicity and leads to a reputation for goods originating from this geographical area, and therefore for its inhabitants. The terroirs are living and innovating spaces that can't be reduced only to tradition». Terroirs are also analyzed as an answer to the

\footnotetext{
13 (IACE) http://www.iace.tn/)

14 Rankings on the ease of doing business (World Bank)
} 
globalization and to the standardization of the consumption by protecting the social and cultural diversity in a sustainable way (Brodharg, on 2000). Besides all the virtues of SMEs that we praised throughout this paper, the terroir enterprise, allows to build the identity of a region and revitalize durably a rural area in desertification phase through the products it delivers [22].Thus, a terroir enterprise is a company which pulls its specificity of links of strong intensity with a soil identified by physical characteristics (geographic and agro-climatic), historical and social, that's to say cultural [23]. So, terroir sector takes a collective form and requires the presence of three key factors: history, soil and entrepreneurial will [24]. Thus, our study concerns entrepreneurial initiatives (individual or collective), generating jobs and wealth and preserving the cultural heritage of the area where they operate. Our research is not interested in the legal form of the entrepreneurial organization but only in its economic and social benefits. Thus, we will include in our research on SMEs, micro-enterprises and other forms that fall in the terroir SME category seen that the object of our study mainly focuses on the entrepreneurial act and the perception of economic and social success.

\subsection{Methodology}

To meet the objectives of our research, we conducted a literature review on SMEs. This literature review allowed us to identify the important role of SMEs in the economic and social fabric of emerging economies. We subsequently focused on the terroir SME which contribute in one way or another to the development of our region of study. Based on this literature review, we conducted an exploratory qualitative study which allowed us to refine our knowledge about the study context. So we conducted semi-structured interviews with a dozen of terroir business leaders. The topics covered include the reasons for the creation, their main problems and their perception of success. We subsequently conducted a quantitative study of 35 companies specialized in the production and marketing of Argan Oil and its derivatives to measure the priority given by the entrepreneurs to the main variables selected for their success.

\subsection{Field of Study}

Region Souss-Massa-Draa (SMD) is located in Morocco. It covers a total area of $70,880 \mathrm{~km}^{2}(10.3 \%$ of national territory). It's a belt while going from the Atlantic Ocean to the Algerian border which divides the country into two parts (parts). This position confers to the region a relay role whence passes all north-south flows and that's what provide it an important strategic economic and socio-cultural roles. It covers two prefectures Agadir Ida Outanane and Inezgane Ait Melloul and five provinces Chtouka Aït Baha, Taroudant, Tiznit, Ouarzazate and Zagora. SMD region has over $50 \%$ of rural population which does not prevent it from recording an unemployment rate of $13.5 \%$ above the national level $(15.4 \%)^{15}$ and contribute to $12.3 \%$ of Morocco's GDP ${ }^{16}$. The region is endowed with a big potential in terroir products due to the conservation of an ancestral knowledge. Among the local products of the region SMD, the Argan is doubtless one of its most known wealth. The argan tree of Morocco is ranked World Biosphere Reserve by UNESCO and is spread over a wooded area of 830,000 ha covering a large part of the SMD region. It plays an important ecological role in the fight against desertification in addition to its socio-economic role in providing income for thousands of rural families according to the Morrocan Ministry of Agriculture and Maritime Fishing. In SMD region, terroir SMEs generally take the form of collective entrepreneurship under the name of income generating activities (IGAs) and are subject to special state attention.

\subsection{Presentation of the Study Sample}

Table 2. Presentation of the study sample

\begin{tabular}{|c|c|}
\hline \multicolumn{2}{|c|}{ Business profile } \\
\hline Year of creation & $\begin{array}{c}\mathrm{N}: 35 \\
\text { Minimum : } 1992 \\
\text { Maximum : } 2013 \\
\text { Mean : 2007,97 } \\
\text { Std. Deviation 3,899 } \\
\end{array}$ \\
\hline Number of employees & $\begin{array}{c}\mathrm{N}: 35 \\
\text { Minimum : 4,00 } \\
\text { Maximum : } 77,00 \\
\text { Mean : 21,5143 } \\
\text { Std. Deviation 19,88995 }\end{array}$ \\
\hline Area of activity & $\begin{array}{c}\text { National Territory: } 85,7 \% \\
\text { National and International : } \\
14,3 \% \\
\end{array}$ \\
\hline \multicolumn{2}{|c|}{ Entrepreneur Profile } \\
\hline Age & $\begin{array}{c}\mathrm{N}: 35 \\
\text { Minimum : } 25,00 \\
\text { Maximum : } 68,00 \\
\text { Mean : 40,6286 } \\
\text { Std. Deviation: } 9,57351\end{array}$ \\
\hline Level of education & $\begin{array}{c}\text { without : } 28,6 \% \\
\text { Elementary school: } 25,7 \% \\
\text { Secondary school: } 25,7 \% \\
\text { with a university degree.: } 20,0 \% \\
\end{array}$ \\
\hline First work experience? & $\begin{array}{l}\text { Yes : } 58,8 \% \\
\text { No : } 41,2 \%\end{array}$ \\
\hline
\end{tabular}

\subsection{Finding}

The majority of terroir SMEs in our region operate in a turbulent landlocked and rural environment. These SMEs are generally grouped under the collective initiatives (IGAs). Our sample is composed of $60 \%$ women's cooperatives and $40 \%$ of individual companies. Aged on average 40 years old and having a relatively low level of education (only $20 \%$ exceeded higher education), the main motivation for the creation of entrepreneurs in our sample is as economic as

15 Region Souss Massa Draa, 2010. Web site: www.regionsmd.com (retrieved 15/06/2014)

16 Regional center of investment (morocco). Publication $\mathrm{N}^{\circ} 12$ June 2010. 
social. The main aspiration of entrepreneurs turns around improving their income $(60 \%)$ followed by the creation of an employment for them or for somebody of their circle of acquaintances $(42,9 \%)$. A minority of the firms of our sample (14.3\%) reached a maturity allowing them to market their products internationally. The collective nature of most companies surveyed reinforces the role of networking and stakeholders in the process of wealth creation for terroir SMEs in accordance with what we have gathered during our exploratory study. Entrepreneurs in our sample give great importance to networking. The same importance is given to the improvement of their income and the production of a social impact through the creation of jobs. Among the striking factors that emerged from our study, the desire of the entrepreneurs to be independent from the external financing which constitutes the most important the challenge for them. The independence of financing is as important to our entrepreneurs as the growth of their project or the improvement of their revenues.

Thus, we asked terroir entrepreneurs on their attitude towards the variables retained from the exploratory study (Networking, Social Impact and Income improvement; Independence from financing, Growth and Income improvement) (Likert scale 1 - 5 from few mattering to very important) starting from the hypothesis of the absence of difference between the two groups of observations. We have opted for the Wilcoxon test, which is effective on small samples and applies on qualitative variables [25] to test this hypothesis.

The significance of this test allows rejecting the null hypothesis concerning the absence of difference between the two groups of observations. The sense of the $\mathrm{Z}$ statistic allows us to conclude that terroir entrepreneurs give more importance to weaving their stakeholder's network rather than producing a social impact. They are also more interested by networking comparing to improving their revenue. Thus we can say that networking is seen as a success indicator by our sample's entrepreneurs. This finding is coherent with the Stakeholder Theory who defines the power in an enterprise as stakeholder's ability to influence an organization to do something it would not otherwise do. It's the same for the independence from financing. Indeed, our sample makes it more relevant than revenue improvement and the project growth. This finding shows a similarity with the Resource-Based View which relates the success of an organization to the resources it possesses [26].

Table 3. Wilcoxon Signed Ranks Test

\begin{tabular}{|c|c|c|c|c|}
\hline & & $\mathrm{N}$ & Mean Rank & Sum of Ranks \\
\hline \multirow[t]{4}{*}{ Networking - Social Impact } & Negative Ranks & $6^{\mathrm{a}}$ & 13,00 & 78,00 \\
\hline & Positive Ranks & $23^{\mathrm{b}}$ & 15,52 & 357,00 \\
\hline & Ties & $6^{\mathrm{c}}$ & & \\
\hline & Total & 35 & & \\
\hline \multirow[t]{4}{*}{ Networking - Income improvement } & Negative Ranks & $5^{\mathrm{d}}$ & 9,20 & 46,00 \\
\hline & Positive Ranks & $22^{\mathrm{e}}$ & 15,09 & 332,00 \\
\hline & Ties & $8^{\mathrm{f}}$ & & \\
\hline & Total & 35 & & \\
\hline \multirow[t]{4}{*}{ Independence from financing- Income improvement } & Negative Ranks & $0^{\mathrm{g}}$ &, 00 & 00 \\
\hline & Positive Ranks & $20^{\mathrm{h}}$ & 10,50 & 210,00 \\
\hline & Ties & $15^{\mathrm{i}}$ & & \\
\hline & Total & 35 & & \\
\hline \multirow[t]{4}{*}{ Growth- Independence from financing } & Negative Ranks & $22^{\mathrm{j}}$ & 12,25 & 269,50 \\
\hline & Positive Ranks & $1^{\mathrm{k}}$ & 6,50 & 6,50 \\
\hline & Ties & $12^{1}$ & & \\
\hline & Total & 35 & & \\
\hline
\end{tabular}

a. Networking < Social Impact; b. Networking > Social Impact; c. Networking = Social Impact; d. Networking < Income improvement; e. Networking > Income improvement ; f. Networking $=$ Income improvement; g. Independence from financing $<$ Income improvement $; \mathrm{h}$. Independence from financing $>$ Income improvement; i. Independence from financing = Income improvement ; j. Growth $<$ Independence from financing; $k$. Growth $>$ Independence from financing; 1. Growth= Independence from financing

Test Statistics

Table 4. Wilcoxon Test Statistics

\begin{tabular}{|c|c|c|c|c|}
\hline & Networking - Social Impact & $\begin{array}{c}\text { Networking - Income } \\
\text { improvement }\end{array}$ & $\begin{array}{c}\text { Independence from } \\
\text { financing- Income } \\
\text { improvement }\end{array}$ & $\begin{array}{c}\text { Growth- Independence } \\
\text { from financing }\end{array}$ \\
\hline Z & $-3,165^{\mathrm{a}}$ & $-3,478^{\mathrm{a}}$ & $-4,055^{\mathrm{a}}$ & $-4,078^{\mathrm{b}}$ \\
\hline Asymp. Sig. (2-tailed) &, 002 &, 001 &, 000 &, 000 \\
\hline
\end{tabular}

a. Based on negative ranks ; b. Based on positive ranks; c. Wilcoxon Signed Ranks Test 


\section{Conclusions}

Closely related to soil, to history and to the local population, Terroir SMEs are vital for the SMD region. On the one hand they allow asserting its identity on the international as having a culture and an ancestral knowledge recognized in terroir products and secondly, these companies contribute significantly to reduce unemployment in the region as shown by our study with an average of 21 jobs created by business. However, SMEs in this sector suffer from several problems among which the dependence of financing who affects the enterprises growth in addition to the entrepreneur's income. So, seen the different challenges that oppose these SMEs, our study suggests adopting a strategy based on network weaving to better promote their products and contribute to the sustainable development of their region. This strategy must be accompanied with the independence from financing to allow these SMEs to grow up and reach an international dimension. Seen that these strategy will probably not be an easy task for an enterprise operating in a developing country, we join Hamimaz [27] about the necessity of states to make greater efforts to value terroir activity in disadvantaged rural areas. Thus, we believe more than necessary the establishment of structures of accompaniment for these entrepreneurs to sustain their economical and social impacts and reducing their financial dependency.

\section{REFERENCES}

[1] Filion, L. J., 1997. Le champ de l'entrepreneuriat : historique, évolution, tendances . Revue internationale PME, vol.10, $\mathrm{n}^{\circ} 2, \mathrm{pp} .129-172$.

[2] Haugh, H. (2007). Community-led social venture creation. Entrepreneurship: Theory \& Practice, 31(2), 161-182.

[3] Tedmanson, D., Verduyn, K., Essers, C., Gartner, W. B. (2012). Critical perspectives in entrepreneurship research. Guest Editors- Organization, sept., vol. 19 (5), pp. 531-541.

[4] Organization for Economic Co-operation and Development (OECD). (2003). Entrepreneurship and local Economic development - program and policy recommendations. ParisFrance.

[5] Bosma, N., Levie, J. (2009). Global Entrepreneurship monitor. Global Report

[6] Peredo, A.M., McLean, M. (2006). Social entrepreneurship: A critical review of the concept. Journal of World Business, 41(1), 56-65.

[7] Verstraete, T. (2002). Essai sur la singularité de l'entrepreneuriat comme domaine de recherche. Les Editions de l'ADREG, Janvier 2002) (ISBN : 2-9517007-0-3)

[8] Marchesnay, M. (2008). «Trente ans d'entrepreneuriat et PME en France : naissance, connaissance, reconnaissance ». Revue internationale P.M.E. : économie et gestion de la petite et moyenne entreprise, vol. 21, n 2, 2008, p.145-168.

[9] Harvie, C. (2004). East Asian SME Capacity Building, Competitiveness and Market Opportunities in a Global Economy. Working Paper 04-16, Department of Economics, University of Wollongong.

[10] Belletante B., Levratto N., Paranque B., (2001). Diversité économique et modes de financement des PME " L'Harmattan (voir "Une présentation de l'ouvrage Diversité économique et modes de financement des PME, Humanisme et Entreprise - numéro 249 octobre)

[11] Miller, D., Toulouse, J., (1986). Strategy, Structure, CEO Personality and Performance in Small Firms. American Journal of Small Business 10, p. 47-62.

[12] Senderovitz, M. (2009), How are SMEs Defined in Current Research? (AGSE).

[13] European Commission. (2011). SBS Factsheet 2010-11, United Kingdom, DG Enterprise and Industry, Brussels. Retrieved 20/06/2014 from

http://ec.europa.eu/enterprise/policies/sme/facts-figures-anal ysis/performance-review/files/countries-sheets/2010-2011/u k_en.pdf

[14] World Business Council for Sustainable Development (WBCSD). (2007). Promoting SMEs for Sustainable Development. WBCSD, July 2007,p2.

[15] European commission. (2012). A recovery on the horizon?. Annual report on European SMEs 2012/2013 p.10.

[16] European commission. (2014). Retrieved 28/06/2014 from http://ec.europa.eu/enterprise /policies/sme /index_en.htm

[17] World Bank. (2013). Doing Business (2014). Comprendre les régulations pour les petites et moyennes entreprises. Washington : Groupe de la Banque mondiale. DOI : 10.1596/978-0-8213-9984-2.

[18] Radas, S, Bozic, L. 2009. The antecedents of SME innovativeness in an emerging transition economy. Technovation 29 (2009) 438-450.

[19] United Nations Economy Commission for Africa Office for North Africa. (2008). SMEs actors for Sustainable Development in North Africa. CEA-AN/PUB/08/2

[20] Elasrag H. 2011. Enhancing the competitiveness of the Arab SMEs. MPRA Paper No. 30018, posted 6. April 2011. Online at http://mpra.ub.uni-muenchen.de/30018/

[21] Hamoumi, S. (2012). La PME Marocaine levier de développement économique et d'innovation. Rencontre des PME Ibéro Américaines et d'Afrique du Nord -Madrid 22 octobre 2012

[22] Polge M. (2003). Petite entreprise et stratégie de terroir. Revue française de gestion, 2003/3 no 144, p. 181-193. DOI : 10.3166/rfg.144.181-193.

[23] Rastoin J.-L.,Vissac-Charles V. (1999). Le groupe stratégique des entreprises de terroir. Revue Internationale PME, Vol. 12, n 1-2, 1999, p. 193-200.

[24] Marchesnay M. (2001). Les PME de terroir : entre "géo » et « clio » stratégies. Entreprises et histoire, 2001/2 $n^{\circ} 28, p$. 51-63. DOI : 10.3917/eh.028.0051.

[25] Carricano, M., Poujol, F., (2008). Analyse de données avec 
SPSS. Pearson Education, 234 p.

[26] Durand, T. (1997). Savoir, savoir-faire et savoir-être. Repenser les compétences de l'entreprise, Actes de la conférence de Montréal, p4.
[27] Hamimaz R. (2009). Le dével oppement des produits du terroir au Maroc : quelques préalables. In : Tekelioglu Y. (ed.), Ilbert H. (ed.), Tozan li S. (ed.). Les produits de terroir, les indications géographiques et le développement local durable des pays méditerranéens. 